\title{
A Comparative Study of Chinese and American Cultural Context and the Influence on Communication*
}

\author{
Jin Tian \\ College of Foreign Languages, Northwest University, Xi'an, China \\ Email: judiasks@163.com
}

\begin{abstract}
Cultural context plays a very important role in intercultural communication between Chinese and Americans. It is different in many ways including: Chinese culture and American culture belong to different cultural types, one high-context culture the other low-context; they are different also in terms of their basic values, language systems and nonverbal communication systems. Only when people from different cultural systems know about the cultural context of the target culture can they have an effective communication. Communication between Chinese and Americans is no exception.
\end{abstract}

Index terms - communication, cultural context, high context culture, low context culture

\section{General InTRODUCTION}

The study of cultural context in communications between Chinese and Americans is very important because "culture is communication and communication is culture". Communication and culture are so closely intertwined that one always embodies his or her cultural characteristics in communication even she or he doesn't realize.

The significance of the study on cultural context about Chinese-American communications is as the following: first and foremost, Chinese culture and American culture are of different types; second, the two cultures are different in terms of their values, language systems, non-verbal systems, and so on; and what's most important is that, as the biggest developing country and developed country in the current world respectively, China and America communicate a lot, there are all kinds of communications and there will be more communications among people of the two countries in different fields including politics, economics, science, education, trade, sports, etc., these communications can happen between government organizations, nongovernmental organizations, and individuals. All these make it crucial for the study of the cultural context between communications of Chinese and Americans.

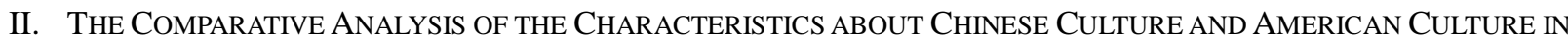
COMMUNICATION

\section{A. The Comparison of Basic Values of the Two Cultures in Communication}

"Although each of us has a unique set of individual values, there are also values that tend to permeate a culture. These are called cultural values." ${ }^{2}$ There are numerous differences between Chinese culture and American culture. "The cultural patterns that are typical of a certain group communicate the essence of that group. Culture distinguishes one group of people from another. ${ }^{3}$ The major characteristics of the Chinese culture and American culture can be briefly summarized as high context oriental culture and low context western culture respectively. Chinese culture has enjoyed a long history. During thousands of years of development, Chinese culture has evolved into a unique culture with its own essence and characteristics. Confucianism becomes the mainstream Chinese culture. Although it's named Confucianism, it's not the mere thoughts of Mencius and Confucius; it's a combination and deposit of the Chinese national culture. It's not one-dimensional but a system of all-round and multidimensional cultural complex. Its cultural spirit is not still, but should be interpreted with the development of the times; its cultural essence should be sublimated.

As to basic American cultural values, it can be mainly summarized as the follows: achievement and success; activity and work; material comfort and practicality; individualism; science and rationality; ethnic group superiority; democracy and law; etc. Individualism, science and rationality will be illustrated as the American values here.

The Americans emphasizes personal rights and responsibilities, giving the individual priority over the group. The Americans have been trained early in their own situation in life and their own destinies. They have not been trained to

\footnotetext{
* This paper is the partial outcome of the research project "Xi' an social science program (10W23).

1 Communication between Cultures, 3rd edition, Larry A. Samovar, Richard E. Porter, Lisa, A Stefani, 2000, Beijing: Foreign Language Teaching and Research Press.

${ }^{2}$ Communication between Cultures, $3^{\text {rd }}$ edition, Larry A. Samovar, Richard E. Porter, Lisa, A Stefani, 2000, Beijing: Foreign Language Teaching and Research Press, p. F21.

${ }^{3}$ Culture and Communication, Zhao Yanping, (1999), China People’s University Press, Beijing.
} 
see themselves as member of a close-knit, tightly interdependent family, religious group, tribe, nation, or other activities. The Americans see themselves as separate human beings who have their own opinions and who are responsible for their own decisions. This perhaps is derived from the early American life and the later development. In early times in America, there was relatively much more land than the population, and the large areas in the west needed many pioneers to work at. People's work and value became more important than that in other countries in terms of individual wisdom and effort. The American western movement was a great opportunity to individuals, for in that period of relatively open society, individuals could improve or change their social positions through self-effort. The American culture expects and encourages independence. From an early age, children are encouraged to make their own decisions and to develop their own skills and abilities.

The Americans like to turn to scientists for solving problems, convinced that the work of scientific experts will improve people's life. They like to regard themselves as rational people. This explains the American cultural tendency to devalue emotional intuition as sources of knowledge. The Americans believe that through science they can gain mastery over the environment and secure a better life. The Americans attach importance to the development of technology from all over the world, and they encourage the scientific invention, and eagerly put them into practical production. The Americans put a high value on science and technology as the predominant means of interacting with the world. This results in objectivity, rationality and materialism.

\section{B. The Comparison of the Language Characteristics of the Two Cultures in Communication}

Language and culture are closely bound up with each other. "Language is the principal means whereby we conduct our social lives. When it is used in contexts of communication, it is bound up with culture in multiple and complex ways." Also, it's further pointed out that 'language expresses cultural reality', 'language embodies cultural reality', and 'language symbolizes cultural reality'. In Chinese-American communications, it's also the case.

The characteristics of Chinese as the Language of the carrier of Chinese culture are mainly revealed in the following aspects: Chinese language is rich in set phrases, proverbs and sayings; the formation of the Chinese personal names is a good reflection of its culture; numerous traditional poetries and set collocations reveal the unique cultural traits; and so on.

Taking Chinese set phrases for example, Chinese set phrases cover a large range of Chinese discourse. Every set phrase has its special source; they are mainly derived from famous classical legends, storied or true events in history. During a long history of several thousand years, set phrases find their way well into Chinese language. Chinese set phrases are not only ample in number, but also very unique in its form and origin. If one can master the Chinese set phrases well, one gets the core value of Chinese culture in a sense. Set phrases in Chinese are conventional, and have long been used in history.

Regarding American English, since America is very advanced and in the leading role in many fields in the world, it makes American English very popular in the world. Since people from other parts of the world all learn American English than vice versa, and since the Americans tend to pertain to their own language, thus the characteristics of American English become more and more apparent. According to my study with the materials available, the traits of American English can be summarized as the following: American English is densely imbedded with Biblical language thus shows a strong flavor of religion and European origin; the way of personal naming of the language is a reflection of its cultural traits of individualism; set phrases and proverbs in the language reflect the unique cultural traits; and so on.

Taking American culture reflected by the sayings and proverbs for example, since American culture mainly derives its content form European culture, which originated from Greek and Roman cultures, it has the basic values similar to them. One very important feature of them is that they are of oceanic culture by nature. So, many of the English idioms are related with navigation. Proverb is also an important form of reflecting a certain cultural values. Many proverbs are employed to teach important lessons that are unique to the particular culture, as is the case of American proverbs and its culture. For example, "Action speaks louder than words." Americans are of a doing culture, hence activity and 'getting things done' are important to the dominant culture. "God help those who help themselves", the saying calls attention to the strong belief in America that people should show initiative. "The squeaky wheel gets grease." In the United States, people are encouraged to speak up and make sure their views are heard.

\section{The Comparison of the Non-verbal Behavior Characteristics of the Two Cultures in Communication}

"Non-verbal communication might be thought of as any form of communication which is not directly dependent on the use of language." 5 The expression of culture is so closely associated with non-verbal communication that the difficulties of learning a culture come more from non-verbal systems than language. The expression of culture is so bound up in nonverbal communication that barriers to culture learning are more nonverbal than verbal. Knowing about the relevance between culture and nonverbal behavior is useful for intercultural communication in many ways. First, by understanding important cultural differences in this behavior, you will be able to gather clues about underlying attitudes and values, since nonverbal communication often reveals basic cultural traits. Second, the study of nonverbal behaviors

\footnotetext{
${ }^{4}$ Intercultural Communication, A Discourse Approach, Ron Scollon, Suzanne Wong Scollon, (2000), Beijign: Foreign Language Teaching and Research Press.

5 Language and Culture, Claire Kramsch, (2000), Shanghai: Shanghai Foreign Language Education Press.
} 
can help people have a tolerant attitude toward others and isolate our own feelings of focusing on our own culture. In one word, studying nonverbal behavior can help people of different cultures understand each other and communicate with each other better.

The study of non-verbal communication is very important regarding the study of communication between Chinese and Americans. The study of non-verbal systems in the study of communication between Chinese and Americans is to solve the problems of communication caused by the cultural differences and negative transfers for the communications.

Chinese culture and American culture are considered as high context culture and low context culture respectively. In terms of non-verbal systems, the two cultures have apparent differences from each other. There are non-verbal behaviors in each culture that can not be found in the other culture. For example, non-verbal behaviors such as Zuoyi, Gongshou, Ketou, and so on, do not exist in American culture; shrugging and kissing on the cheek do not show up in Chinese culture. Furthermore, although some non-verbal behaviors exist in both cultures, they have different implications. For example, hand in hand may have different meanings between people of different relationships in Chinese culture, whereas in American culture, it's mainly a non-verbal behavior between lovers.

A culture's use of time can provide valuable clues to how members of that culture value and respond to time. Taking the view of time in Chinese culture as nonverbal behavior for example, in Chinese culture, time is thought of as the rotation of a circle, going repeatedly round and round and thus the past is cherished and revered. So in Chinese, we have the saying like: "Consider the past and you will know the present.", "The sun alternates with the moon; autumn returns after spring soon", "Think three times before you act", and so on. These reflect our culture worshiping the tradition of ancestors and the strong pride of having a brilliant and persistent long history.

As for the nonverbal behavior of American culture, here eye movement will be analyzed. America is a highly industrialized society, where people act with great speed. Everyone has a lot to do with his own business, and they are used to being indifferent to others around, especially those in the streets or the like. In addition, they do not care much about other people's business. So that's why people usually try to avoid looking at others as passersby or as onlookers. In America, many large cities are made up of totally strangers. Even though it is very crowded, there are not much things directly related to them. People have formed the habit of not looking at others. Their refusal of looking into others' eyes has led to less communication and interaction with others, and newcomers from other places will feel a certain kind of hostility and unfriendliness.

\section{CONCLUSION}

With the above analysis about the cultural context of Chinese-American communications, we can come to the conclusion as the follows: Studying cultural context in communication between Chinese and American culture is of great significance both theoretically and practically. In modern world, international communication promotes progress in large scales and many ranges. With regard to communication between Chinese and Americans, the case is especially true. Cultural context is indispensable for effective communication between Chinese and Americans. Chinese culture and American culture are considered different in the sense that Chinese culture is high-context culture and American Culture low-context culture.

\section{REFERENCES}

[1] Larry A. Samovar, Richard E. Porter, Lisa, A Stefani, (2000). Communication between Cultures. 3rd edition, Beijing: Foreign Language Teaching and Research Press, p. F21, p60.

[2] Zhao Yanping. (1999). Culture and Communication. Beijing: China People's University Press, P2.

[3] Ron Scollon, Suzanne Wong Scollon. (2000). Intercultural Communication: A Discourse Approach. Beijing: Foreign Language Teaching and Research Press, P142.

[4] Claire Kramsch. (2000). Language and Culture. Shanghai: Shanghai Foreign Language Education Press.

[5] Vincent. (1997).Strangers to these shores. Miami: Warner Bros Publications.

[6] Kneth, Averil, Philip. (2001). Human Diversity in Education. New York: R.R. Donnelley Company.

[7] Gleason. (1993). The Development of Language. Boston: Merrill Publishing Press.

[8] Babbie. (1996). The Practice of Social Research. New York: Wadsworth Publishing Company.

Jin Tian was born in Weinan, China in 1971. She received her M.A. degree of English Language and Culture from Northwest University in 2003, and Ph.D degree of history from Northwest University in 2009.

She is currently an associate professor in College of Foreign Languages, Northwest University, Xi'an, China. Her research interests include history and culture and cross-cultural communication. 